Discourse and Communication for Sustainable Education, vol. 10, no. 1, pp. 5-19, 2019

\title{
Education for Sustainability: Developing Ecocritical Literature Circles in the Student Teacher Classroom
}

\author{
Lykke Guanio-Uluru \\ Western Norway University of Applied Sciences, Bergen, Norway
}

\begin{abstract}
How can student-teachers learn efficient ways to encourage sustainability thinking in their pupils and fulfil the competence aims on sustainability outlined in national subject curriculums as a response to UNESCO's programme on Education for Sustainable Development, ESD? The core hypothesis of this project was that tailored literature circles, focused on the ecocritical aspects of literary texts, would make student-teachers aware of how they can use literature as a process to reflect on sustainability. This would enable them to incorporate sustainability thinking into their own teaching practices.

The project's tailoring of the standard literature circle roles (Daniels 1994, 2002, 2006) involved the design of reading roles that highlighted ecocritical and generic aspects of the studied texts and the application of an analytical matrix developed by literary scholars researching the representation of nature in children's and young adult literature. This article presents the results of a small-scale study testing the ecocritical literature circles approach and its impact on student-teachers' conception of their own ability to meet the competence aims on sustainability in their teaching. The intervention included lectures on ecocriticism and on the posthuman debate prior to the literature circles and student feedback through pre- and post-circle questionnaires. It was implemented in the teacher-training classroom, working with dystopian science fiction texts for young adults. These texts present the reader with visions of the future. The study showed that the ecocritical literature circles, and in particular the ecocritical reading roles, were considered useful by the participating student-teachers. The participants also reported a significant increase in confidence relative to their own ability to discuss sustainability issues with their pupils.
\end{abstract}

Keywords: ecocriticism, teacher education, posthuman, literature circles, education for sustainable development (EDS), young adult literature.

\section{Literature and Sustainability: An Ecocritical Perspective}

The study on ecocritical literature circles was framed in response to UNESCO's programme on Education for Sustainable Development, ESD (see Leicht et al., 2018). This underlines the role of education in enabling children and young adults to face 
global environmental challenges. ESD answers goals 4 and 13 of the United Nation's 17 sustainability development goals (UN, 2018). Goal 4 centres on providing education and lifelong learning for all. Goal 13 centres on improved education and awarenessraising relative to climate change.

Sustainability competence is currently becoming increasingly central to subject curriculums worldwide. In Norway, the Framework Plan for Primary and Lower Secondary Teacher Education now lists as a general competence aim that teachers should be able to "encourage democratic participation and sustainable development" (Norwegian Ministry of Education and Research, 2016a). The question is: how are student-teachers enabled to fulfill this competence aim related to sustainable development? Results from this pilot study suggest that Norwegian teacher education currently lacks methodological tools that enable student-teachers to develop the competence required in order to be able to encourage sustainable development in their pupils. This gap between policies and practices manifests in other countries as well. In a study of student-teacher's views on competencies in education for sustainable development in Barcelona, Spain, Gisela Cebrián and Mercè Junyent (2015) note that "existing ESD theoretical frameworks need to become more alive and integrated within the existing teacher education curriculum to promote the awareness and development of ESD competencies amongst student-teachers (p. 2783).”

With sustainability now included as a cross-curricular theme in Norwegian subject curricula (Norwegian Ministry of Education and Research, 2016b), a pertinent question for literature teachers is: How can literature help teachers and student-teachers encourage sustainable development? UNESCO outlines eight cross-cutting key competencies for sustainability: systems thinking competency (to recognize and understand relationships and systems); anticipatory competency (the ability to create and evaluate visions for the future); normative competency (ability to reflect on norms and values); strategic competency (ability to develop and implement innovative actions); collaboration competency (ability to learn from, work with and relate respectfully to others); critical thinking competency (ability to question norms, practices and opinions); self-awareness competency (ability to reflect on one's own role in the local and global communities); and integrated problem-solving competency (ability to apply different problem-solving frameworks to complex sustainability problems) (UNESCO, 2017).

The present study addresses several of these competencies and suggests that reflection on and discussion of literary texts, within the theoretical framework of ecocriticism and assisted by the pedagogical framework of literature circle discussion, can help develop key competencies of sustainability as well as assist the formation of eco-centered perspectives. As defined by Iliško et al. (2017), "Sustainability pedagogies are considered to be innovative pedagogies that foster values that lead to behaviour change and cause students to be more sustainability oriented" (p. 15). Literary texts are useful points of departure for raising environmental awareness because literature presents the reader with constructed environments and actions, and in children's and young adult literature, these environments are specifically shaped in order to socialise children and young adults into ways of being and behaving. These texts thus frequently have a pedagogical foundation, and the values embedded in the narratives are those of the (adult) authors who constructed the texts. Geraldine Massey and Claire Bradford (2011) have consequently argued that ecocritical children's texts may construct ecocritical awareness in the reader provided that the reader adopts the reading position invited by the text, since this may lead to an adoption of the world view advocated by the literary narrative. 
So, what are ecocriticism and ecocritical awareness? In the 1990s, Cheryll Glotfelty defined ecocriticism as "the study of the relationship between literature and the physical environment” (Glotfelty \& Fromm 1996, xix). Nearly two decades later and incorporating the expansion of ecocriticism to include the posthuman debate on interspecies relations and geopolitics (Braidotti, 2013; Hayles, 1999; Haraway, 1991, 2008, 2016; Wolfe, 2010), Greg Garrard offers a much wider definition: "ecocriticism is the study of the relationship of the human and the non-human, throughout our cultural history and entailing critical analysis of the term 'human' itself" (2012, p. 5). Consequently, an ecocritical perspective involves examining how human-nature relationships are represented in literary texts, acknowledging the formative power of such representations. Broadly speaking, all texts and cultures contain culturally established figures of thought that shape and affect our understanding of the world, including our understanding and knowledge of nature and the human. As an example, examining the global discourse on species extinction, Ursula Heise (2017) convincingly demonstrates how the majority of fictional and nonfictional texts that portray endangered species rely on the genre templates of elegy and tragedy. Furthermore, she discusses how global biodiversity databases are founded on the template of the encyclopaedia, but also of the epic, as they portray a global struggle in which the future of life and the planet itself are at stake. Based on her readings, which encompass analyses and comparison of the biodiversity laws of America, Germany, the EU and Bolivia, Heise shows that through their local and historic foundations, "biodiversity, endangered species, and extinction are primarily cultural issues, questions of what we value and what stories we tell" (2017, p. 5). Like-wise, Timothy Morton (2007) argues that we need to consider how nature is constructed in art, since "it is in art that the fantasies we have about nature take shape" and since our cultural ideas of nature are currently "getting in the way of properly ecological forms of culture, philosophy, politics, and art” (p. 1). It is thus a highly potent and important exercise to examine culturally constructed figures and configurations of thought relative to nature and the environment. Children's and young adult literature provide fertile sites for such exercises.

There is an apparent need for ecocritical approaches to sustainability. In their study of student-teacher's views on education for sustainable development, Cebrián and Junyent (2015) conclude:

This study suggests that student-teachers understand ESD as an education that focuses mainly on the natural environment, instead of providing a more integrated vision, where the social, environmental, economic and cultural aspects are interrelated and essential to work in the school environment to provide students with a more holistic and complex worldview (p. 2783).

The methodology of ecocritical literature circles furthers such an integrated vision of sustainability.

\section{Methodological Tools: Ecocriticism, Reading Roles and the Nature-in-Culture Matrix}

This article reports results from a small-scale study conducted to test the hypothesis that the use of literature circles is a viable pedagogical tool for teaching sustainability issues. The literature circle approach was chosen to implement dialogue around sustain- 
ability issues, both in order to engage the student's collaborative competency and to facilitate student engagement. Literature circles are a form of student-driven collaborative learning that allows students to take responsibility for the literary discussion. With this approach, students form, or are placed in, groups to discuss literary texts, having first prepared points for discussion connected to their specific reading roles. Teachers and students in Chicago and Arizona developed the literature-circles approach simultaneously and independently in a US context in the early 1980s, "bringing the established adult literacy structure of voluntary reading groups into the public schools" (Daniels, 2006). Since then, the approach has been widely used to meet a variety of teaching aims on a variety of teaching levels. Literature circles have been used within social studies teaching (McCall, 2010), and to teach social issues (Noll, 1994) and science (Straits and Nichols, 2006). These projects have relied on Daniels' $(1994,2002)$ standard reading roles, developed to mimic a competent reader: discussion director (prepares higher level thinking questions); literary luminary (selects important passages for discussion); word wizard (selects important words for discussion); researcher (prepares background information); scene setter (attention to setting(s)); and connector (finds connections between text and real world). As the approach has become more widespread, the reading roles have also been modified to teach science literacy (Miller et al., 2007; Devick-Fry and LeSage, 2010) and Common Core State Standards (Barone, 2013), but there is no published research on the use of tailored literature circle roles to teach sustainability issues. While Daniels warns of a "terminology drift" within education, where new ideas and practices for use that are widely adopted consequently departs ever further from the original idea or practice $(2006$, p. 10). The ecocritical literature circle approach retains a close enough connection to the original practice to warrent the use of the term "literature circles", even as the roles are modified to serve new aims. This position is supported by the fact that Daniels cautions against the over-dependence on his original reading roles (2006, p. 11).

This project was initiated to develop and encourage student-teachers' reflection on sustainability and a more nuanced student-teacher vocabulary tied to ecocritical and posthuman issues. This was necessary to present student-teachers with a viable, easyto-use methodology responding to the needs generated by the new, cross-curricular competence aim of sustainability recently introduced for student-teachers in Norway, but with international relevance. As Rizzo (2011) notes, 'research has shown literature circles to be an effective way to combine cooperative learning, independent reading and quality group discussion'. The approach has been adapted to improve vocabulary in content courses (Miller et al., 2007) and to focus on science matierial in novels (Straits and Nichols, 2007). The method thus represents a promising path for increasing student vocabulary and reflection related to ecocriticism and sustainability thinking. This is supported by Daniels' assertion that 'lit circles are essentially well-structured collaborative learning applied to reading' (Daniels, 2006, p. 13).

As noted by Frough and Karimnia (2018, p. 64), sustainable teaching "promotes competencies like critical thinking and making decisions in a collaborative way". A pedagogical approach combining the collaborative method of literature circles with critical reflection on literary texts reflects and promotes these competencies. The ecocritical literature circle project's tailored version of the literature circles approach was based on combining student feedback from the researcher's previous work with crossnational literature circles and on participation in an international research project analyzing 
representations of nature in children's and young adult literatures and cultures. In order to enable ecocritical analysis and comparison across a range of texts, from novels to picture-books, digital apps, films - and even of educational practices, the NaChiLitCul research group, based at Western Norway University of Applied Sciences, has developed an analytical matrix, the Nature in Culture Matrix (see Figure 1). The Matrix is based on joint readings and discussions of key ecocritical concepts and texts, and on the group's combined expertise in the fields of children's and YA literature and culture (see Goga et al., 2018, pp. 12-13). This matrix forms part of the methodological tools supporting the implementation of this ecocritical literature circles project.

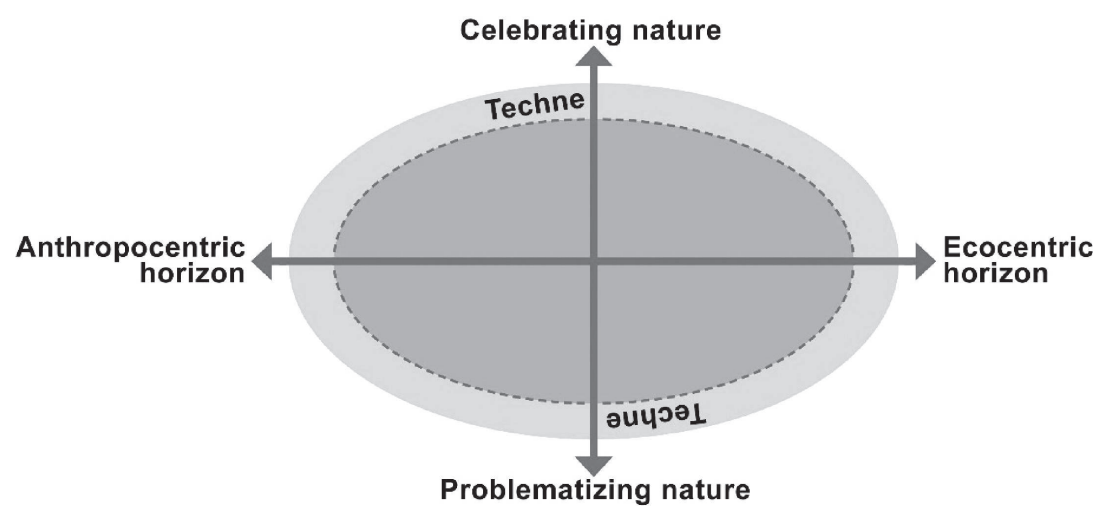

Figure 1. Nature in Culture Matrix

The matrix takes the form of a system of coordinates in which a variety of cultural expressions can be discussed in relation to a vertical continuum ranging from a celebration to a problematization of nature, and a horizontal continuum ranging from an anthropocentric to an ecocentric horizon. The lines of the matrix represent how divergent views of nature are dependent on how humans position themselves, ontologically and relationally. On the vertical axis, the celebrating position implies an idea of the "child of nature", a Romantic figure that is central to the cultural and pedagogical tradition, based primarily on the reception of Rousseau's Emile (2010/ 1762). The problematizing position takes account of the escalating environmental challenges and the growing engagement with ecocritical concerns in children's and young adult (YA) literature, demonstrating a more critical and problematizing awareness of nature. The horizontal axis depicts a continuum ranging from anthropocentric perspectives on nature towards a more ecologically oriented view. The idea of human exceptionalism relative to other species, which is central to the anthropocentric position, gains traction both from the Judeo-Christian Genesis (1:28) and from Ancient Greek philosophy. Anthropocentrism thus underpins much of the Western philosophical tradition. Literature and cultural practices may sustain this humancentred understanding of nature, or challenge it by taking a more ecocentric view, valuing all species more equally.

The matrix is circumscribed by the dimension of techne, which here is understood as the art of shaping and manufacturing: the "intentional crafting of self, world, and society" (Boellstorff 2015, p. 55). This dimension signals the fact that children's and YA texts are already mediated and thus "crafted" representations of nature. Furthermore, it calls attention to recent developments within bio-technology, in which nature increas- 
ingly is subject to cultural influence and human manipulation. The matrix has been conceived as an organic analytical figure. It has evolved over time, in response to different texts (literary and critical) and scholarly discussions. The matrix was revisited several times in class during the intervention.

As a practical aid guiding the students to adopt an ecocritical research perspective, the literature-circle reading roles were tailored to focus attention on ecocritical aspects of the studied texts. The ecocritical reading roles formulated for this project were nature scribe; plant and animal watcher; dystopian detective; and biotechnology detector. The roles of nature scribe and the plant and animal watcher represented a way for students to engage directly with an ecocritical perspective, because the roles served as lenses that focused student attention on description of landscape, flora and fauna in the literary texts. The additional reading roles of dystopian detective and bio-technology detector were designed to help the students bring the generic and posthuman aspects of the studied texts into focus, encouraging them to reflect on posthuman issues and on the way that bio-technology alters our relationship to nature and the natural. The roles were deliberately made quite specific, to provide an ecocritical lens through which the students could approach the texts, even with no significant prior knowledge of ecocriticism. The aim was to test whether these reading roles can function as an easyto-use ecocritical approach.

The reading roles came with the following written instructions:

Nature scribe: find passages describing nature and the environment / landscape. What role does nature play in the: a) plot? b) characterization (description of the characters)? Does nature play a symbolic role in the novel?

Plant and animal watcher: pay particular attention to how plants and animals are described. Find sample passages for discussion. a) Are plants and animals presented as valuable in themselves or are they only significant relative to their use for humans? b) What role(s) do plants and animals play in the story?

Dystopian detective: what traits, typical of dystopian fiction, does the novel display? a) Find key traits and passages that mark the text as dystopian fiction (see article by Hintz on your reading list). b) Remember that the dystopian detective also facilitates the discussion.

Bio-technology detector: find passages describing the use of bio-technology. What role does bio-technology play in the a) plot? b) characterization (description of the characters)? Does bio-technology play a symbolic role in the novel?

The ecocritical literature circles approach thus rested on the triple base of ecocriticism, tailored literature circle roles, and on the application of the Nature in Culture Matrix.

\section{Research Methodology}

The present pilot study was conducted with Norwegian student-teachers preparing to teach English as a Foreign Language (EFL). The reading was a mandatory part of their tuition. This aspect of the project thus departed from Daniels' (2006) emphasis on choice (11), since the students did not choose their own reading material nor their discussion groups. As the researcher had no previous knowledge of the student group, the reading roles were randomly assigned, as were the groups. The class had used the standard literature circle roles once before with a different teacher. 
The student-teachers filled out informed consent forms prior to the study and were asked to complete written, analogue and anonymous, pre-study and post-study questionnaires following the educational intervention in order to facilitate an evaluation of the study. It was made explicitly clear to the student-teachers that although they had to participate in the coursework in class, they could withdraw their participation in the research project at any time. They were thus given a choice about whether or not to answer the questionnaires. The majority of student-teachers were quite positive about participating in the study.

In order to provide the student-teachers with some degree of context for the use of ecocritical literature circles, they had two sets of lectures ( $3 \times 45 \mathrm{~min}$ sessions) the week before the circle discussions, combined with student-teachers reflection tasks and whole class discussions. The first set of lectures introduced the concept and practice of ecocriticism and involved reflections around varying attitudes to nature, and reflections around the analytical matrix. The second set of lectures treated the concept of the posthuman, asking the student-teachers to discuss questions like "what is nature?" and to reflect on how cultural attitudes shape our attention to and treatment of nature. The second lecture set also introduced the dystopian genre, based on the Introduction from Carry Hintz and Elaine Ostry's Utopian and Dystopian Writing for Children and Young Adults (2003), which was on the student-teachers' reading list.

The anonymous pre-circle questionnaire was designed to gauge the student-teachers' pre-project familiarity with the concepts of ecocriticism, the posthuman and sustainability as defined within humanities disciplines. A further aim with the pre-project questionnaire was to investigate whether the student-teachers felt that their teacher education had prepared them for teaching sustainability issues and whether they felt confident in using literature to this end. After completing the two rounds of literature circles the studentteachers were given a post-circle questionnaire.

The pre-project questionnaire consisted of 10 questions, three of which asked the student-teachers to define the terms ecocriticism, the posthuman and sustainability in their own words. Six questions with a scale from 1-5, asked the student-teachers to rate their interest in sustainable development, their competence related to teaching sustainable development and their confidence in using literary texts to this end. The last question was an open question asking the student-teachers about their expectations towards participating in the research project. The post-project questionnaire was somewhat longer and consisted of 15 questions. It repeated some of the questions from the pre-project questionnaire in order to assess student-teacher learning. It also asked the student-teachers to evaluate the different aspects of the project in scaled responses from 1-5 relative to the lessons, the in-class reflection tasks, the literature circle discussions, their own preparations and the use of the analytical matrix. The last question was open, inviting an evaluation of the project. Both the pre- and post-project questionnaires contained a mixture of quantitative (scaled) and qualitative questions. The questionnaires were completed in class, on paper forms to ensure respondent anonymity. The student-teacher's responses to the qualitative questions in the questionnaires were analysed using thematic analysis (Braun and Clarke, 2006).

For the literature circles, the student-teachers were assigned two best-selling young adult dystopian novels as reading material. Suzanne Collins' The Hunger Games (2011/ 2008) highlighted how biotechnology is used for medical and cosmetic purposes but also to manufacture biological weapons, and Scott Westerfield's Uglies (2012/2005), 
which highlighted how bio-technology is used for cosmetic purposes but also as a means of social and political control.

The student-teachers were placed into groups, each group comprising all the four ecocritical reading roles. The dystopian detective had an additional role as the facilitator of the discussion. When working with larger groups, the number of roles could be increased, incorporating for instance the standard role of the word wizard and / or the connector. The student-teachers were asked to submit a short reflection note prior to each circle, (one set of notes for each novel), to help them prepare for the circle discussions. After each round of literature circles, the Nature in Culture Matrix was re-introduced in class, as a tool for discussing the attitudes to nature displayed in the two texts.

In response to UNESCO's eight cross-cutting key competencies, the study was designed to activate in particular the student-teachers' normative self-awareness and critical thinking competencies. The intention was to stimulate critical reflection on ethically challenging literary texts and the student-teachers' anticipatory competency. This was accomplished through the choice of genre (the reading material was dystopian science fiction texts that present alternative visions of the future). The student-teachers' collaboration competency was activated through the methodology of literature circles, and their systems thinking competency through engagement with an analytical model (see Figure 1).

\section{Research Findings}

Sixteen student-teachers completed both the pre- and post-project questionnaires. The results from the study's pre-project questionnaire shows that none of the studentteachers initially felt prepared by their teacher education to teach sustainable development, see Table 1.

Table 1

Responses to the Question in the Pre-Project Questionnaire: 'My teacher education has prepared me to teach sustainable development'. Scaled response:

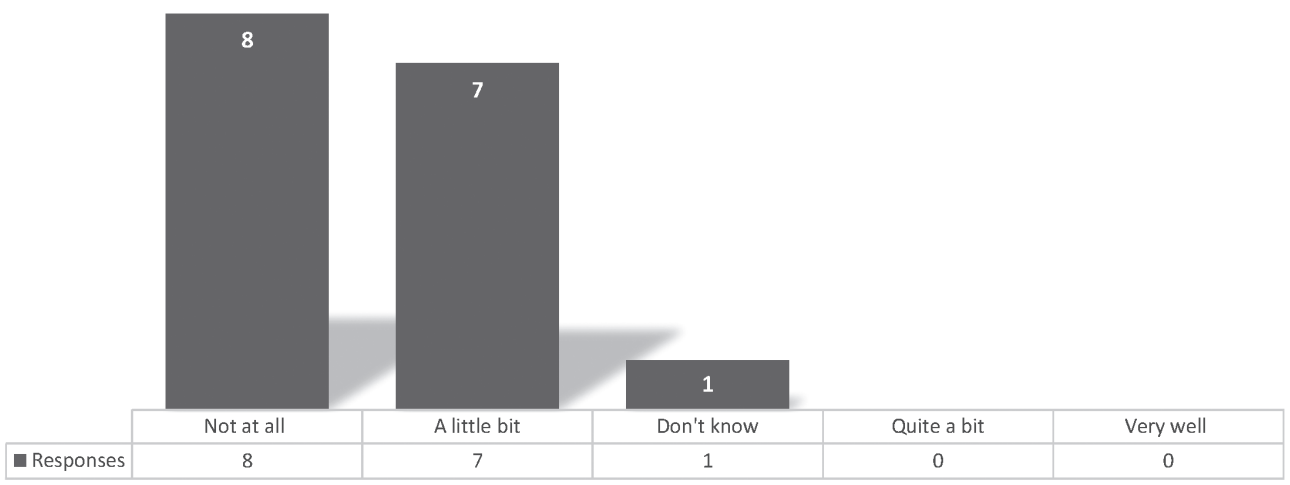

In the table, the student-teachers' replies are clustered at the responses "not at all" and "a little bit", with one student-teacher expressing uncertainty about how well s/he had been prepared by his or her teacher education to tach sustainable development. 


\section{Impact on Perceptions of Sustainability and Comprehension of Terms}

When asked in the pre-project questionnaire to define sustainability in their own words, $50 \%$ of the student-teachers defined sustainability as the use of resources in a way that does not deplete them for future use, all specifically mentioning the future or future generations, for instance: 'It's when you continue using/producing something at a rate that won't be detrimental to future use of the environment.' $18.75 \%$ of the student-teachers linked sustainability to the climate and to global warming and one response related sustainability to the UN's goals for sustainable development. A single student-teacher responded, 'I don't know', and there was one response defining sustainability as related to teaching: 'For me it means to chose (sic) my teaching methods and what I teach, in light of the level of my students.'

In the post-project questionnaire, $50 \%$ of the student-teachers still defined sustainability in relation to the use and depletion of resources, but now only one response specifically mentioned the future: 'Sustainable is the idea of renewable, long lasting. Sustainable is to act with care for the future and future generation (sic)'. A typical kind of statement was now: "It means being able to "keep up" something, often in the context of taking care of the environment and making sure it does not become damaged".' $12.5 \%$ of the student-teachers now related sustainability to specific attitudes to nature: awareness of our treatment of nature as well as the development of a non-hierarchical relationship to nature, something that was discussed in the lectures on the post-human. In the postcircle questionnaire, another $12.5 \%$ defined sustainability in terms of taking action: to recycle or fix broken things. There was a slight shift in the students' conception of how important sustainability is after the implementation of the project, see Table 2.

Table 2

Responses to the Question in the Pre-and Post-Project Questionnaires: 'How important is sustainability?'

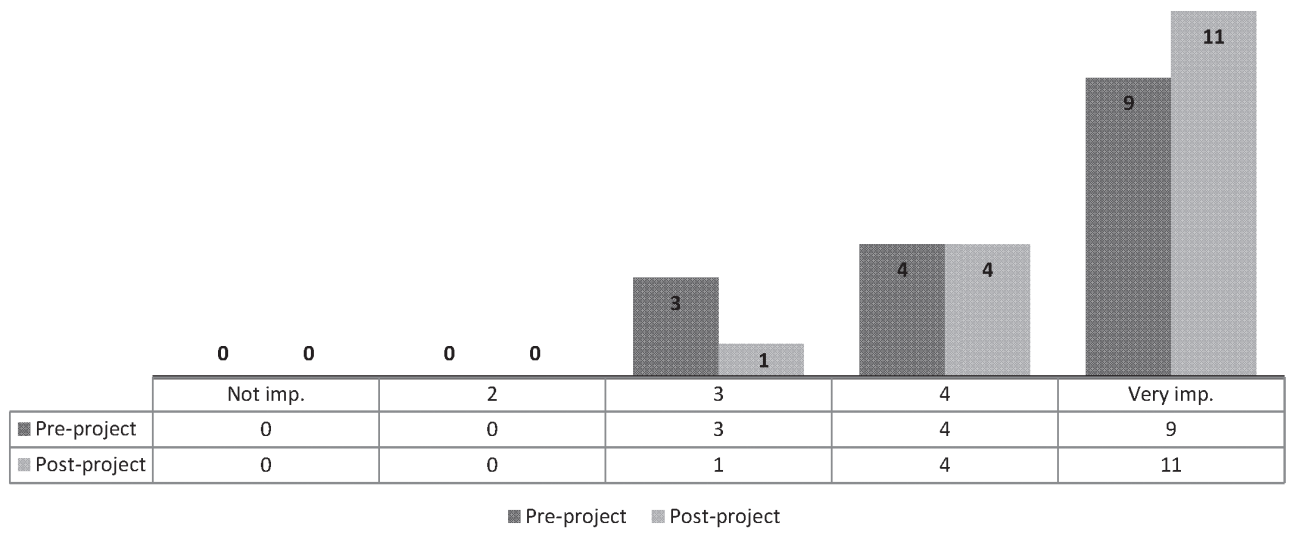

Table 2 indicates that the student-teachers considered sustainability to be somewhat more important after the intervention.

When asked to define ecocriticism before the project, only $12.5 \%$ could link the term to literature, as in: 'Critical reflection on representations of nature' and 'Focus on the global ecological crisis through the intersection literature and culture.' $37.5 \%$ linked 
ecocriticism to global warming acceptance or denial and $31 \%$ replied 'I don't know.' In the post-project questionnaire, $50 \%$ of the student-teachers linked the term to literature and the environment or to cultural reflections on ecology. There was one reply stating: 'I never understood what it meant', and one response leaving the space blank. $37.5 \%$ replied that ecocriticism concerns how we treat the environment, but without specifically linking the term to literature.

The student-teachers were also asked to define posthuman before and after the project. In the pre-project questionnaire, $62.5 \%$ replied that they did not know the term or what it meant. $27 \%$ attempted to guess at the meaning based on etymology, replying that it was something that 'comes after the age of man' or 'after the human'. Two responses linked the term to machines and robots. The most creative interpretation was 'Someone who delivers mail', which likely was intended as a joke.

In the post-project questionnaire, $37.5 \%$ of the student-teachers had quite detailed definitions of the posthuman, saying things like: 'The posthuman is an idea that our species is evolving from where we are now towards new and "improved" versions of ourself $(s i c)$. This improvement has both risks and ethical dilemmas that are attached to the concept' and 'The posthuman is a term describing what our species can develop into using advanced bio-technology, drugs that enhance performance. Changing our fysical (sic) and psychological features for the better. Making us run faster, stronger muscle power, enhanced intelligence. Manipulating DNA and genes to makes us immune from diseases.' $50 \%$ had simpler definitions, relating the concept mostly to the future development of humanity, as in 'Posthuman is how things will be in the future, technology etc.' and 'Posthuman is the life after the humans living in the world today. How would the world look like in for example 300 years from now?' One respondent said: 'I'm unsure' and in one response 'posthuman' was defined as 'supernatural humans', a reference, perhaps, to technological enhancement. These figures show that the project to some extent was successful in introducing the student-teachers to the concepts of ecocriticism and the posthuman that are complex concepts for first language learners, let alone for students approaching them in a foreign language.

\section{Student-Teacher Responses to the Literature Circle Roles and the Nature in Culture Matrix}

When asked to rate the usefulness of the literature circle roles on a scale from 1-5, $75 \%$ of the student-teachers ticked a 4 or 5 , see Table 3 . This is quite a high score, indicating that the ecocritical literature circle roles functioned well.

Table 3 shows that most of the student-teachers found the ecocritical reading roles quite or very useful.

The student-teachers struggled a lot more with the analytical matrix. This is not surprising, since the figure is derived from a complex set of background data. As such, it challenged the student-teachers' systems thinking competency. Although the studentteachers were introduced to the concepts of the matrix in the lectures, two rather brief encounters with the matrix used as an analytical tool is not much. Still, most of the student-teachers were willing to struggle past their initial frustration to arrive at a place where they found the matrix useful or interesting. In response to the question: 'What are your thoughts on the Nature in Culture Matrix?' $31 \%$ found it too difficult to be of 
use, while $62.5 \%$ found it interesting or useful despite their initial confusion. These statements are representative: “It's a good tool for creating discussion. It is hard to place something in the matrix, but it has important points to think about', 'I think it is useful in discussion. A bit confusing at times, but I feel that this is part of the discussion' and 'Confusing, many difficult word (sic). But it also made it easier to understand some parts of the book and their relation to sustainability and nature.' The remaining responses were neutral, simply describing the matrix.

Table 3

Responses to the Question in the Post-Project Questionnaire: 'How useful were the ecocritical reading roles?'

\section{Reading roles}

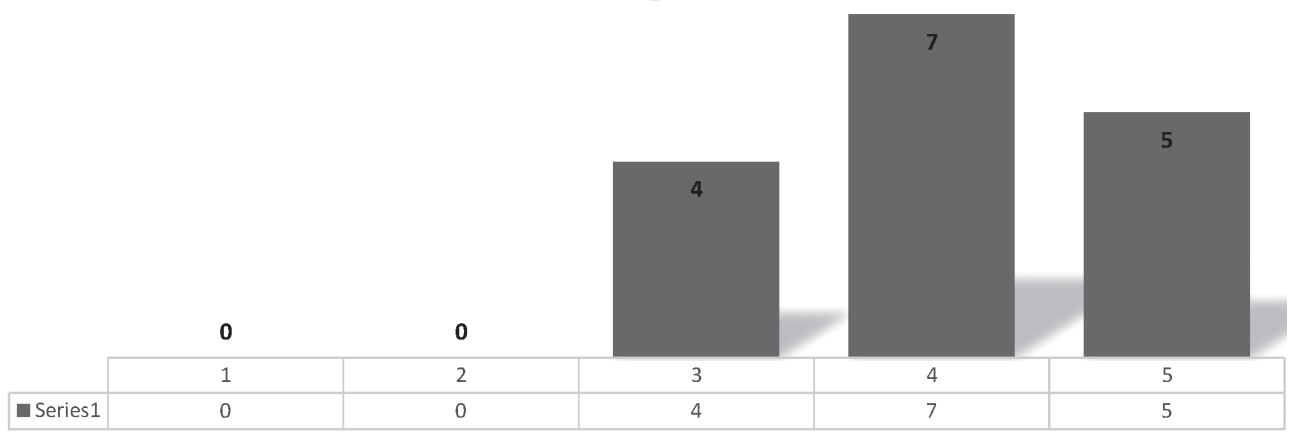

In response to the claim 'I will use ecocritical literature circles in my own teaching practice', $68.75 \%$ responded 'I will try' or 'I will use them sometimes', while $18.75 \%$ responded 'I don't know'. Only $12.5 \%$ said they will 'never' use ecocritical literature circles in their own teaching practice.

\section{Competence Building}

While the student-teachers' responses to the methodology of ecocritical literature circles were overall very positive, their increased sense of competence as a result of participating in the project is striking. In response to the question 'I know how to use literary texts to discuss sustainability with my pupils', rated in a span from 'not at all' to 'very well', 93.75\% of the student-teachers responded between the one and two in the pre-project questionnaire. In the post-project questionnaire, 56\% responded with a 4 or 5 , and no student-teachers respond with a 1 or 2 , see Table 4.

Table 4 shows that in effect, the perception of the whole group shifted from a feeling of having hardly any idea of how to use literary texts to discuss sustainable development to a feeling of confidence in using this approach to teaching and raising awareness on sustainability issues. 
Table 4

Responses to the Question in the Pre-and Post-Project Questionnaires: "I know how to use literary texts to discuss sustainability with my pupils."

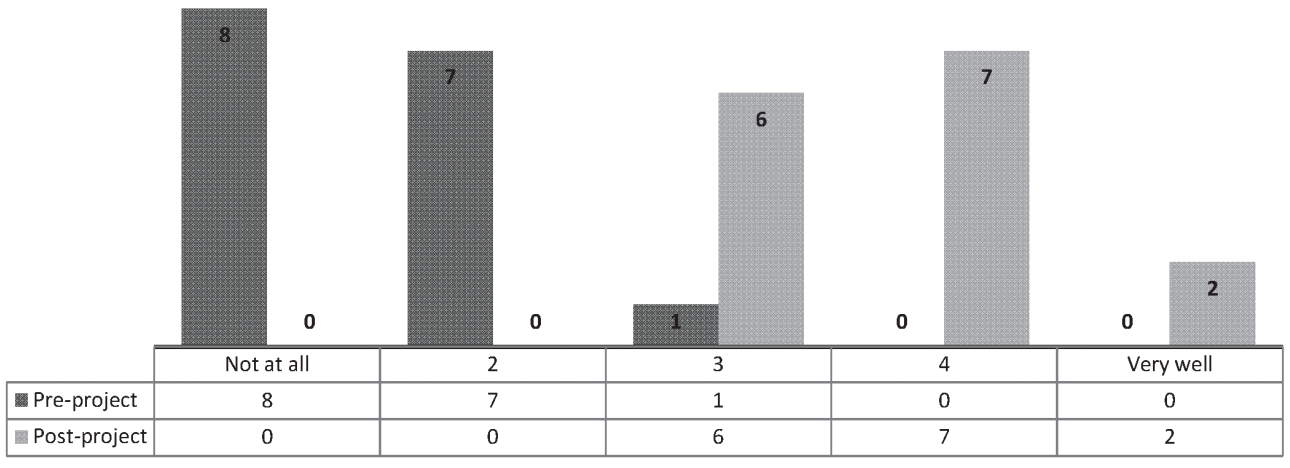

Pre-project $=$ Post-project

\section{Discussion and Conclusion}

The detected shift in the student-teachers' definition of sustainability from one of describing it in terms of its significance for the future to the omission of references to the future in the post-circle questionnaire was unexpected and surprising. In conjunction with a slight increase in student-teacher perception of the importance of sustainable development, one might speculate that the intervention has brought the concept closer to the here and now. This is supported by the $12.5 \%$ share of the student-teachers that define sustainability in terms of taking action (to recycle or fix broken things) in the post-project questionnaire, whereas none of the student-teachers has this actionorientation in the pre-project questionnaire. It could also signal that the student-teachers in their post-questionnaire definitions relied less on the much-cited definition of sustainability from the Brundtland Report (in which sustainability is linked to development and defined as the kind of development that meets present needs without compromising the ability of future generations to meet their needs, see (UN, 1987)).

The two other striking points in the student feedback is the extent to which they report in the pre-project questionnaire that their teacher education so far has failed to prepare them to teach sustainable development (see Table 1). Significantly, they also report the impact the intervention has had on their sense of confidence in their own ability to use literary texts to discuss sustainability issues with their pupils (see Table 4).

A post-project pedagogical reflection includes the possibility that reversing the implementation order of the reading circles and the lectures might be worth considering, since the reading roles proved easy for the student-teachers to engage with. The lectures, which conveyed more abstract and unfamiliar material, would then function as an expansion of the encounter with an ecocritical approach afforded by the more handson literature circle discussions rather than as contextual preparation for the implementation of the circles. The reading roles would then be the first stage in a Vygotskian inspired type of educational scaffolding, supporting student-teachers as they advance towards more developed perspectives on ecocritical and posthuman ideas. 
Overall, the project was successful in fostering confidence in the participant studentteachers relative to their own ability to use literature to teach sustainability issues. The methodology of ecocritical literature circles developed though this project thus enables student-teachers to meet the new competence aim on sustainability outlined in the Framework Plan for Primary and Lower Secondary Teacher Education. Although implemented here with Norwegian EFL student-teachers, ecocritical literature circles holds great promise as a general teaching strategy when working to incorporate the competence aim on sustainability into teacher education. The students displayed great interest in and dedication to the project and it was highly rewarding to listen in as they engaged with and discussed ecocritical perspectives on literary texts in their literature circle groups, as well as in class.

\section{References}

Barone, D. (2013). Tweaking literature circles: A: Las Vegas schoolteacher aces the common Core. Reading Today. December 2013, online /January 2014.

Boellstorff, T. (2015). Coming of age in Second Life: An anthropologist explores the virtually human. Princeton: Princeton University Press.

Braidotti, R. (2013). The posthuman. Cambridge: Polity Press.

Braun, V., \& Clarke, V. (2006). Using thematic analysis in psychology. Qualitative Research in Psychology, 3(2), 77-101.

Cebrián, G., \& Junyent, M. (2015). Competencies in education for sustainable development: Exploring the student-teachers' views. Sustainability, 7(3), 2768-2786.

Collins, S. (2008). The hunger games. London: Scholastic.

Daniels, H. (1994). Literature circles: Voice and choice in the student-centred classroom. Portland, ME: Stenhouse.

Daniels, H. (2002). Literature circles: Voice and choice in book clubs and reading groups. ( $2^{\text {nd }}$ Ed.). Portland, ME: Stenhouse.

Daniels, H. (2006). What's the next big thing with literature circles? Voices from the Middle, 13(4), 10-15.

Devick-Fry, J., \& LeSage, T. (2010). Science literacy circles: Big ideas about science. Science Activities: Classroom Projects and Curriculum Ideas, 47(2), 35-40.

Garrard, G. (2012). Ecocriticism. New York: Routledge.

Glotfelty, C., \& Fromm, H. (Eds.). (1996). The ecocriticism reader. Landmarks in literary ecology. Athens: The University of Georgia Press.

Goga, N., Guanio-Uluru, L., Hallås, B. O., \& Nyrnes, A. (Eds.). (2018). Ecocritical perspectives on children's texts and cultures: Nordic dialogues. Basingstoke: Palgrave Macmillan.

Haraway, D. (1991). A cyborg manifesto: Science, technology, and socialist-feminism in the late twentieth century. Simians, cyborgs and women: The reinvention of nature. Routledge, 149-81.

Haraway, D. (2008). When species meet. Minneapolis: The University of Minnesota Press.

Haraway, D. (2016). Staying with the trouble: Making king in the Chthulucene. Durham: Duke University Press.

Hayles, N. K. (1999). How we became posthuman. Virtual bodies in cybernetics, literature, and informatics. Chicago: The University of Chicago Press. 
Heise, U. (2016). Imagining extinction: The cultural meanings of endangered species. Chicago: The University of Chicago Press.

Hintz, C., \& Ostry, E. (2003). Utopian and dystopian writing for children and young adults. London: Routledge.

Iliško, D., Olehnoviča, E., Ostrovska, I., Akmene, V., \& Salìte, I. (2017). Meeting the challenges of ESD competency - based curriculum in a vocational school setting. Discourse and Communication for Sustainable Education, 8(2), 103-113.

Leicht, A., Heiss, J., \& Byun, W. J. (Eds). (2018). Issues and trends in Education for Sustainable Development. Paris: UNESCO. Retrieved from https://unesdoc.unesco. org/ark:/48223/pf0000261445

Massey, G., \& Bradford, C. (2011). Children as ecocitizens: Ecocriticism and environmental texts. In K. Mallan \& C. Bradford (Eds.). Contemporary children's literature and film: Engaging with theory (pp. 208-217). Basingstoke: Palgrave Macmillan.

McCall, A. L. (2010). Teaching powerful social studies Ideas through literature circles. Social Studies, 101(4), 152-159.

Mehrparvar, F., \& Karimnia, A. (2018). Second language teaching effectiveness from the perspective of university students: A case study of departments of applied linguistics. Discourse and Communication for Sustainable Education, 9(1), 64-78.

Miller, L., Kucan, L., \& Dass, M. (2007). Literature circles roles for science vocabulary. The Science Teacher, 74, 52-54.

Morton, T. (2007). Ecology without nature: Rethinking environmental aesthetics. Cambridge: Harvard University Press.

Noll, E. (1994). Social issues and literature circles with adolescents. Journal of Reading, 38(2), 88-93.

Norwegian Ministry of Education and Research. (2016, June). Framework plan for primary and lower secondary teacher education. Retrieved from: https://www. regjeringen.no/contentassets/fbaf26939bbd40abacba73e 34a95d2fc/forskrift-omrammeplan-for-grunnskolelarerutdanning-for-trinn-1-7.pdf

Norwegian Ministry of Education and Research. (2016, November). Proposal for Renewal and Improvement of School Subjects. Retrieved from https://www.regjeringen.no/ en/aktuelt/proposal-for-renewal-and-improvement-of-school-subjects/id2483423/

Peralta-Nash, C., \& Dutch, J. A. (2000). Literature circles: Creating an environment for choice. Primary Voices, K-6 8.4, 29-37.

Straits, W., \& Nicolls, S. (2006). Literature circles for science. National Science Teacher Association Web News, October 30 ${ }^{\text {th }}$. Retrieved from http://www.nsta.org/ publications/news/story.aspx? $\mathrm{id}=52824$

Rizzo, S. (2011). Developing dynamic classroom interaction through reading circles. AUC TESOL Journal. Retrieved from https://www3.aucegypt.edu/auctesol/ Default.aspx? issueid=dc82a931-ec50-4ac8-98a3-4878b73f0399\&aid=d03ca6d64242-4325-a79f-f39ceff31918

Rousseau, J. J. (2010 [1762]). Emile (Collected writing of Rousseau). Edited by C. Kelly. Translated by Kelly, C. and A. Bloom. New Hampshire: Dartmouth College Press.

UNESCO. (2017). Education for Sustainable Development Goals: Learning Objectives. Paris: UNESCO. Retrieved from http://unesdoc.unesco.org/images/0024/002474/ 247444e.pdf

UN. (1987). Our Common Future. Retrieved from http://www.un-documents.net/ocf02.htm\#I 
UN. (2018). The Sustainable Development Goals Report. Retrieved from https://unstats. un.org/sdgs/files/report/2018/TheSustainableDevelopmentGoalsReport2018.pdf

Westerfield, S. (2012 [2005]). Uglies. New York: Simon and Schuster.

Wilfong, L. G. (2009). Textmasters: Bringing literature circles to textbook reading across the curriculum. Journal of Adolescent \& Adult Literacy, 53(2), 164-171.

Wolfe, C. (2010). What is posthumanism? Minneapolis: University of Minnesota Press.

Correspondence regarding this article should be addressed to Lykke Guanio-Uluru, Faculty of Education, Arts and Sports, Western Norway University of Applied Sciences, Inndalsveien 28, 5063 Bergen, Norway. Email: hagl@hvl.no 